\title{
Workplace Inclusion from the Standpoint of Individuals with Intellectual Disabilities
}

\author{
Nara Liana Pereira-Silva ${ }^{1, *}$ \\ Orcid.org/0000-0002-8435-3078 \\ Adelaine Vianna Furtado ${ }^{2}$ \\ Orcid.org/0000-0003-3352-3812 \\ Jaqueline Ferreira Condé de Melo Andrade ${ }^{1}$ \\ Orcid.org/0000-0002-1303-2867
}

${ }^{1}$ Universidade Federal de Juiz de Fora, Juiz de Fora, MG, Brasil ${ }^{2}$ Centro de Referência de Assistência Social da Prefeitura Municipal de Muriaé, MG, Brasil

\begin{abstract}
Inclusion in the job market offers intellectually disabled individuals the possibility of social and emotional development. The present study sought to explore several aspects of the workplace inclusion process of individuals with intellectual disabilities, based on their accounts of personal experiences. The study enjoyed the participation of four women and five men between 23 and 40 years of age and diagnosed with intellectual disabilities. All of the participants had prior employment experience; four were employed at the time, and five were unemployed. In order to collect the research data, the participants were visited at their homes, where they answered a questionnaire and a semi-structured interview. The results of the interviews revealed that the workplace inclusion process is largely satisfactory and that inclusion is a right. The results thus indicate that the inclusion context is capable of aiding the development of autonomy, independence, personal satisfaction, productivity and responsibility. We stress the importance of preparing studies aimed at improving the workplace inclusion process, highlighting its role in the development of people with intellectual disabilities by providing empirical data that can support the planning and implementation of public policies on workplace inclusion.
\end{abstract}

Keywords: Intellectual disability, labor market, inclusion.

\section{A Inclusão no Trabalho sob a Perspectiva das Pessoas com Deficiência Intelectual}

\section{Resumo}

A inclusão no mercado de trabalho representa, para as pessoas com deficiência intelectual, a possibilidade de desenvolvimento social e emocional. O presente estudo teve por objetivo investigar

* Mailing address: Rua José Lourenço Kelmer, s/n, Martelos, Juiz de Fora, MG, Brazil 36036-330. E-mail: naraliana.silva@ufjf.edu.br

Financial aid: Coordenação de Aperfeiçoamento de Pessoal de Nível Superior (Capes).

Author's note: The present article is part of the master's dissertation defended by the second author with the academic counseling of the first author. 
aspectos relacionados à inclusão no trabalho de pessoas com deficiência intelectual, a partir de relatos de experiências. Participaram quatro mulheres e cinco homens com idades entre 23 a 40 anos e diagnóstico de deficiência intelectual. Todos os participantes já possuíam experiência de trabalho, sendo que quatro estavam empregados e cinco estavam desempregados. Para a coleta de dados, os participantes foram visitados em suas residências, tendo respondido a um questionário e a entrevistas semiestruturadas. Os resultados das entrevistas demonstraram que a inclusão no mercado de trabalho é um processo mais satisfatório do que insatisfatório, além de ser um direito. Os dados apontam, portanto, que este contexto pode favorecer o desenvolvimento da autonomia, independência, satisfação pessoal, produtividade e responsabilidade. Ressalta-se a importância do planejamento de estudos que visem aprofundar o processo de inclusão no trabalho, destacando seu papel para o desenvolvimento das pessoas com deficiência intelectual, fornecendo dados empíricos que possam subsidiar a implementação e o planejamento de políticas públicas de inclusão.

Palavras-chave: Deficiência intelectual, mercado de trabalho, inclusão.

\section{La Inclusión en el Trabajo desde la Perspectiva de las Personas con Discapacidad Intelectual}

\section{Resumen}

La inclusión en el mercado de trabajo representa para las personas con discapacidad intelectual la posibilidad de desarrollo social y emocional. El presente estudio tuvo como objetivo investigar algunos aspectos de la inclusión laboral de personas con discapacidad intelectual a partir de relatos de experiencia. Participaron del estudio cuatro mujeres y cinco hombres con edades entre los 23 a 40 años que han sido diagnosticados con deficiencia intelectual. Todos los participantes ya tenían algún tipo de experiencia laboral; cuatro de ellos estaban trabajando, mientras que los otros cinco se encontraban desempleados. Para la recolección de datos los participantes fueron visitados en sus residencias respondiendo a un cuestionario y a entrevistas semiestructuradas. Los resultados de las entrevistas demostraron que la inclusión en el mercado de trabajo es un proceso más satisfactorio que insatisfactorio. Por tanto, los datos señalan que este contexto puede favorecer el desarrollo de la autonomía, independencia, satisfacción personal, productividad y responsabilidad. Es de resaltar la importancia de futuras investigaciones que profundicen en la inclusión laboral, destacando su papel para el desarrollo de personas con discapacidad intelectual proporcionado datos empíricos que puedan sustentar el diseño y la implementación de políticas públicas para la inclusión.

Palabras clave: Deficiencia intelectual, mercado de trabajo, inclusión.

In the course of history, various paradigms have influenced the establishment of laws and the manner in which disabled individuals have been, and continue to be, treated in society. In recent times, the inclusion model has been affecting policies focused on persons with disabilities (Araújo, Escobal, \& Ribeiro, 2006; Mantoan, 2015; Mendes, 2006; Paiva, Bendassolli, \& Torres, 2015; Sassaki, 1997). From the standpoint of the inclusion paradigm, disabilities are not embedded in individuals in the sense that such persons alone are responsible for their own development, but rather society as a whole is also responsible for discovering means of furthering the development and inclusion of disabled persons, taking into account such people's right to access to the common property of life in society (Aranha, 2001; Barbosa-Gomes \& Carvalho, 2010; Mantoan, 2015). Accordingly, concepts such as social inclusion, participation in the community and empowerment have been essential to the formulation of public policies, 
legislation and services aimed at individuals with intellectual disabilities - IDs (Morin, Rivard, Crocker, Boursier, \& Caron, 2013).

Along these lines, the job market is one of the most important contexts for adults with IDs, for it is an environment in which such adults can exercise their citizenship and develop social, intellectual and interpersonal abilities. Job-market access on the part of individuals with disabilities has historically been guaranteed by legal provisions. Within the Brazilian context, ever since the Brazilian Constitution of 1988 (Article 37, Section VIII), disabled individuals' inclusion in relation to job openings has been recognized, particularly when such inclusion involves public-employment hiring quotas for such persons. Such rights were reinforced in 1990 by Federal Law No. 8112, which, in its fifth article, proposed reserving a portion of public job openings for people with disabilities and defined the criteria for such hiring (Federal Law No. 8112, 1990). In 1991, Brazilian Federal Law No. 8213, also known as the "Law of Quotas," considerably altered the manner of incorporating disabled people into organizations that hire employees (Cezar, 2010; Lobato, 2009). The Law of Quotas sets forth social security plans and benefits and establishes, by way of affirmative action, hiring quotas for disabled individuals, obliging companies with 100 or more employees to fill from 2 to $5 \%$ of their job openings with people with some form of disability (Federal Law No. 8213, 1991). Also known as the Brazilian Inclusion Law (Federal Law 13,146, 2015), Federal Law 13,146 of July 2015 went into effect in 2016. Among other rights, it guarantees disabled people "the right to jobs they freely and voluntarily choose, in an accessible, inclusive environment and on a basis of equal opportunity with respect to other people." This law has made important advances in terms of guaranteeing fundamental rights not only in the occupational domain, but also in education, accessibility and the fight against bias and discrimination. At the international level, ever since 1946 the Universal Declaration of Human Rights had already guaranteed all people "the right to work, to free choice of employment, to just and favourable conditions of work and to protection against unemployment" (World Health Organization [WHO], 1948, p. 12), considering employment a necessity and a human right.

Nonetheless, in spite of the movement centered on the inclusion and legal guarantees offered, few people with IDs are actually incorporated into the job market, and those who are included face countless difficulties in terms of keeping their jobs (Almeida, Carvalho-Freitas, \& Marques, 2010; Furtado \& Pereira-Silva, 2014; Lobato, 2009; Paiva et al., 2015). Data from Brazil's 2010 census indicated the existence of 45.6 million people with disabilities, representing $23.9 \%$ of the Brazilian population in 2010 . Of this total, only $46.2 \%$ of those of working age engaged in some form of occupational activity. People with intellectual disabilities represent $1.4 \%$ of the overall population of people with disabilities in Brazil; and, of those of working age, only $20.2 \%$ of the men and $14.2 \%$ of the women actually work. People with IDs are thus assimilated the least by the job market, as compared to people with other disabilities, such as physical, visual and hearing impairments (Instituto Brasileiro de Geografia e Estatística [IBGE], 2012). Among the factors that contribute to this scenario, it is worth highlighting the following: noncompliance with legal provisions, the need for career training programs, the lack of physical and social accessibility in companies, and bias in relation to hiring people with intellectual disabilities (Araújo \& Schmidt, 2006; Lobato, 2009; Masson, 2009; Nord, Luecking, Mank, Kiernan, \& Wray, 2013; Nota, Santilli, Ginevra, \& Soresi, 2014; Tanaka \& Manzini, 2005; Vornholt, Uitdewilligen, \& Nijhuis, 2013).

Notwithstanding the existing challenges, the pursuit of concrete action aimed at intellectually disabled people's actual inclusion in the job market is fundamental, since the work environment is a developmental context, facilitating (or not) the development of personal identity and abilities, the fulfillment of basic necessities and personal aspirations, participation in the social and economic development of the community, and one's sense of personal appreciation (Gold, Fabian \& Luecking, 2013; Kirsh et al., 2009; Lysaght, Cobigo, \& Hamilton, 2012; Lysaght, 
Petner-Arrey, Cobigo, \& Oullette-Kuntz, 2014; Nord et al., 2013; Nota et al., 2014; Vornholt et al., 2013). Furthermore, people with IDs can potentially enjoy the expansion of their networks of social interaction, establishing social and professional relationships with individuals that have no disabilities (Lysaght et al., 2012; Nota et al., 2014; Vornholt et al., 2013) and thus reducing their social isolation (Vieira \& Denari, 2008).

From the standpoint of Akkerman, Janssen, Kef, and Meininger (2014) and of PereiraSilva and Furtado (2012), one of the principal courses of action necessary to provide satisfactory support and reduce barriers to job-market inclusion is to survey people with IDs in order to discover what they themselves consider important to achieve job satisfaction. Pereira-Silva and Furtado studied the inclusion process of four intellectually disabled job trainees between 19 and 32 years of age who had job experience in retail stores. The results of the interviews revealed that the trainees' lack of vocational preparation and their personal and socioemotional issues as well as the companies' unpreparedness to hire employees with IDs were the factors that were most responsible for the failure of their job-market inclusion. The authors stress the importance of dialogue between vocational schools and companies that receive such employees.

Akkerman et al. (2014) examined nine intellectually disabled individuals' viewpoints in relation to job satisfaction. For data collection, the researchers employed the photovoice [participatory photography] method, whereby the participants took photos of their work environment and later, during an interview, described their photographic records. Analysis of the interviews produced nine topics, each of which was capable of positively or negatively influencing perceptions of job satisfaction. The participants largely identified the type of work, the circumstances in which it was performed, and the social interactions established during such employment as being conditions that were essential to their satisfaction in each respective environment. They also mentioned the importance of both the support they received and the opportunities they were given to apply their skills. Although less frequently (possibly due to being more difficult to express, according to the researchers), the intellectually disabled employees also described the work demands they experienced, the autonomy they perceived, their opportunities for growth/development, and the significance of their work.

The literature on the subjecthas demonstrated that individuals with IDs encounter difficulties in terms of both obtaining employment and keeping their jobs. This issue served as a guide for a study conducted by Holwerda, van der Klink, de Boer, Groothoff, and Brouwer (2013) that, through the use of a follow-up, examined the variables that influence behavior that involves acquiring and keeping jobs; 735 intellectually disabled Dutch adults between 15 and 27 years of age participated in the study. Motivation, expectations as to job advancement, and housing situation were found to be the principal variables that predict obtaining and keeping a job. According to the authors, when adults possess motivation and positive expectations in relation to their capacity to work, they feel motivated to seek employment or to keep the job for which they were hired. With respect to the housingsituation variable, participants in the study who were living with their families or by themselves achieved greater success in terms of acquiring and keeping jobs than did those who were living in institutions. The authors concluded that it is fundamental for parents, teachers and other professionals both to encourage adults with IDs to express their desires, expectations and interests in relation to employment and to help them develop realistic expectations, thus also cultivating a work atmosphere in which individuals with IDs receive constant support to retain their jobs.

It is worth stressing the importance of employment as an opportunity for intellectually disabled adults to achieve satisfaction in life and, consequently, better life quality. Along these lines, Santilli, Nota, Ginevra, and Soresi (2014) surveyed 120 intellectually disabled Italian employees in terms of life satisfaction associated with career adaptability and expectations. They discovered correlations between these two 
variables, thus implying the existence of a connection between willpower to commence and continue goal-targeted behaviors and the procedures/means to achieve objectives, which leads to greater life satisfaction. According to the authors, such findings reveal the importance of activities that encourage adaptation to a career, promoting motivational development and life quality in the workplace. Furthermore, the authors stress the importance of the role of the employees that work alongside these individuals: Such coworkers should encourage them and promote activities/interventions that help them plan future goals, focusing on their potential rather than on their shortcomings and difficulties.

The workplace environment's importance to individuals with IDs is thus undeniable. As indicated by Furtado and Pereira-Silva's findings (2014), this is a growing field of study that is still in its infancy, requiring additional research. Accordingly, aiming at answering the question "How have intellectually disabled individuals" occupational experiences been?," the present study's general objective was to examine factors related to intellectually disabled people's inclusion in the job market, based on their accounts of such experiences, focusing on the following: (a) their school days; (b) what being employed means to them; (c) their perceptions of both their workplace environment and interpersonal relationships; (d) their respective families' roles in relation to such inclusion; (e) their occupational achievements; and (f) their employment expectations.

\section{Method}

\section{Participants}

The present study enjoyed the participation of nine adults diagnosed with an ID. Their participation in the study was conditioned upon satisfying the following criteria: (a) having been diagnosed with an ID (without comorbidities) by a physician or by way of a psychosocial/psychopedagogical report; (b) being at least 18 years of age; (c) cohabiting with parents or guardians, with no marital commitments; and (d) being employed or having employment experience. Table 1 characterizes each participant in terms of his/ her gender, age, diagnosis, educational level and employment status. In order to anonymously identify the participants, each of them was assigned the letter "P" followed by a number.

Table 1

Identification of Intellectually Disabled Participants by Sex, Age, Diagnosis, Schooling, and Employment Status

\begin{tabular}{cccccc}
\hline Participant & Sex & $\begin{array}{c}\text { Age } \\
\text { (years })\end{array}$ & Diagnosis & Schooling & $\begin{array}{c}\text { Employment } \\
\text { Status }\end{array}$ \\
\hline P1 & Male & 23 & Mental Retardation & No Formal Schooling & Employed \\
P2 & Female & 26 & Down Syndrome & High School Diploma & Employed \\
P3 & Male & 29 & Mental Retardation & No Formal Schooling & Employed \\
P4 & Female & 40 & Down Syndrome & No Formal Schooling & Employed \\
P5 & Male & 30 & Mild Mental Retardation & Incomplete Elementary Schooling & Unemployed \\
P6 & Female & 36 & Mild Mental Retardation & High School Diploma & Unemployed \\
P7 & Male & 33 & Severe Mental Retardation & No Formal Schooling & Unemployed \\
P8 & Female & 28 & Down Syndrome & No Formal Schooling & Unemployed \\
P9 & Male & 25 & Mild Mental Retardation & Incomplete Elementary Schooling & Unemployed
\end{tabular}

a The original medical terms employed at the time of the participants' diagnoses have been preserved here. Accordingly, the term "mental retardation" in the present Table refers to the currently employed term "intellectual disability." 
At the time of data collection, five participants were unemployed and four were employed. Of the nine participants, four were women and five were men. Five of them had no formal education, classified as "no formal schooling"; and two had completed high school.

Table 2 presents data related to the participants' employment status, highlighting the job performed, the length and location of such employment, the number of hours worked per day and the days on which they worked. One observes a wide range of jobs performed, with most of the participants working as assistants $(n=5)$. One also perceives a 40.2-month average length of employment for the group of employed participants (P1, P2, P3 and P4); and a 15.2-month average, for the unemployed group. The number of hours worked daily varied, with some participants working four hours a day $(n$ $=3)$; others, six hours $(n=3)$; and yet others, up to eight hours $(n=2)$. The days on which they worked also varied: Monday-Friday $(n=$ 4), Monday-Sunday $(n=2)$, and according to a variable shift plan $(n=3)$.

Table 2

Intellectually Disabled Participants' Occupational Characteristics by Job Position, Place of Work, Length of Employment, Hours Worked Daily, and Days Worked

\begin{tabular}{|c|c|c|c|c|c|}
\hline Participant & Job position & Place of work & $\begin{array}{l}\text { Length of } \\
\text { emplymt. } \\
\text { (months) }\end{array}$ & $\begin{array}{c}\text { Hours } \\
\text { worked } \\
\text { daily }^{\mathrm{a}}\end{array}$ & Days worked \\
\hline $\mathrm{P} 1$ & Packer & Supermarket & 48 & 4 & Variable shift plan \\
\hline $\mathrm{P} 2$ & Typist & Metal mfg. company & 6 & 6 & Mon-Fri \\
\hline P3 & General service assistant & Snack bar & 48 & 6 & Variable shift plan \\
\hline $\mathrm{P} 4$ & General service assistant & Snack bar & 60 & 6 & Variable shift plan \\
\hline P5 & $\begin{array}{c}\text { Cargo } \\
\text { assistant }\end{array}$ & Printing company & 48 & $*$ & Mon-Sun \\
\hline P6 & Domestic servant & Private residence & 9 & 8 & Mon-Fri \\
\hline P7 & $\begin{array}{c}\text { Office } \\
\text { assistant }\end{array}$ & $\begin{array}{c}\text { Steel } \\
\text { company }\end{array}$ & 6 & 4 & Mon-Fri \\
\hline P8 & Secretary & $\begin{array}{c}\text { Steel } \\
\text { company }\end{array}$ & 9 & 4 & Mon-Fri \\
\hline P9 & $\begin{array}{l}\text { Butcher } \\
\text { assistant }\end{array}$ & Supermarket & 4 & 8 & Mon-Sun \\
\hline
\end{tabular}

a Participant P5 did not report the number of hours worked daily.

\section{Instruments}

The present study employed a Family System Characterization Questionnaire (Dessen \& Cerqueira-Silva, 2009), which was used to ascertain the demographic characteristics of the participants' families and which encompasses items that relate to the participants' parents and to their families in general as well as questions concerning the intellectually disabled participants' abilities, diagnoses and employment situations. We prepared two semi-structured interview scripts based on the recommendations of Lobato (2009) and of Masson (2009), one for the intellectually disabled individuals who were working and the other for those who were unemployed. The interviews sought to discover the participants' career-development and educational backgrounds, their expectations as to employment inclusion, and their feelings and reactions in relation to both their employment experiences and the support received from their families. 


\section{Data Collection Procedures}

The present study's potential participants were selected from a list of employment candidates of a job placement program run by an institution that assists disabled persons in a city in the interior of the state of Minas Gerais, Brazil, and via our contact with an institution that provides specialized assistance in the same city. Of the potential participants, we chose nine individuals with IDs because they met the following criteria: (a) having been diagnosed with an ID (without comorbidities) by a physician or by way of a psychosocial/psychopedagogical report; (b) being at least 18 years of age; (c) cohabiting with parents or guardians, with no marital commitments; and (d) being employed or having employment experience. We contacted the nine individuals, by phone or in person, in order to explain the study's objectives and verbally request their consent to take part in the research. Visits to their respective homes were scheduled according to their convenience and availability. During such visits, each participant signed an informed consent form, answered the questionnaire and gave a personal interview, which was recorded with a digital audio device and later entirely transcribed for content analysis purposes.

\section{Data Analysis Procedures}

In order to analyze the responses to the questionnaire, we employed descriptive statistics; and for the interviews, we performed the analysis based on Dessen and Cerqueira-Silva's proposed model (2009), which entails the following procedures: (a) selection and examination of the material, known as pre-analysis; (b) coding; (c) theme grouping; (d) formation of synthesis categories; (e) theme classification; and (f) determination of categories. Supplementary to the preceding procedures, the present study's authors recommend including the following: (g) revision of the preliminary system of categories and elaboration of the integrated (final) system; and (h) validation of the integrated system, based on an assessment by judges.

\section{Ethical Procedures}

The present study was approved by the Human Research Ethics Committee of the Federal University of Juiz de Fora, Opinion No. 118/2011. Furthermore, all participants signed an informed consent form.

\section{Results}

The results are initially presented for the categories we identified as being common to the statements of both the employed and unemployed participants. We then present the results of the categories we identified separately in the interviews of the employed and unemployed participants.

\section{Educational Background}

Of the nine participants, five limited their schooling-related statements to mere descriptions of the schools they had attended; three provided vague, imprecise information as to a certain moment or incident they experienced during their schooling period, not answering the question directly; and one participant alone reported that he did not recall his school days, thus providing no information in this respect. Examining the statements, one perceives the participants' difficulty to describe this period of their lives, especially because it required them to recall such a remote time.

\section{The Significance of Being Employed}

The participants' statements revealed that "being employed" signifies (a) achieving financial gains $(n=5)$ and (b) attaining personal gains $(n=4)$. One participant did not comment on the meaning of being employed. The financial gains that were mentioned related to financial independence $(n=2)$, sustenance of their household/ home/life $(n=2)$ and acquisition of possessions and leisure $(n=1)$, while personal gains included personal satisfaction $(n=2)$, productivity $(n=$ $1)$ and responsibility $(n=1)$, as indicated by the following accounts:

Financial Gains: 
Financial independence: "Well... I have my own money..." (P1).

Sustenance of household/home/life: "Being employed means improving the situation here at home" (P8).

Acquisition of possessions and leisure: “. . . you have your own money, buy clothes, sneakers, and go out on the town" (P9).

Personal Gains:

Personal satisfaction: "Well, what it means is Ifeel good"' (P5).

Productivity: "I'll be productive, producing" (P6).

Responsibility: "To me, being employed means having scheduled hours, waking up early... Actually, I'm responsible, for sleeping early, at the right time; I get ready early and go to work" (P2).

The participants' responses indicated that their becoming interested in working was due to (a) their motivation to purchase things via the remuneration received for being employed ( $n=$ 1); (b) the encouragement they received from their families $(n=1)$; and (c) the intercession of the specialized care institutions they attended ( $n$ $=2$ ). Some of the accounts were vague and imprecise $(n=4)$, and one participant was unable to answer the question. Grouped in accordance with the predetermined categories, several examples of the participants' statements are presented below.

Motivation to purchase: "My interest in working is mostly related to being able to buy the things I need, you know..." (P5).

Encouragement from family members: “Well, my mom would say 'you have to work, 'so I'd look and look [for work]..." (P6).

Intercession of institutes: "My boss, named $C ., \ldots$ he was there at $X$ [specialized institution] and brought me to work here at $Z$ [hiring company] . . So, through X, I was sent there" (P3).

In relation to their satisfaction with workplace inclusion, the participants stated that the process was satisfactory $(n=4)$; was unsatisfactory $(n=2)$; is a right $(n=1)$. One of the participants mentioned not knowing how to talk about the subject; and another provided vague, impre- cise information. The following accounts typify the categories identified:

Satisfactory: "I think it's really good, you know. . . I think [an individual with a disability] gains the potential to work..." (P2). "Yeah, it's good, isn't it?" (P5).

Unsatisfactory: "They are highly unappreciated, because the people that are more than you are think they're better than you, and everybody's in the same bracket, earning the same amount..." (P3)

A right: "... I don't want to say that other people are better than we are; everything in life has laws, and the law has to be obeyed" (P8).

\section{Perceptions as to the Workplace Environment and Interpersonal Relationships}

We examined the working conditions of both the employed and unemployed participants, having requested them to describe their jobs' physical environments, made up of items such as the furniture and the equipment utilized, and social environments, namely the individuals and the participants' interactions with their coworkers and employers. Most of the participants' accounts described both the physical environments and the social settings as satisfactory $(n=7)$. We identified one account in which the social setting was described as initially satisfactory; and another account that provided imprecise or vague information. Examples of the participants' statements, grouped according to the categories, are presented below.

Satisfactory physical and social environment: "It's peaceful over there... the people are nice, they would help me" (P6). "So . . I like it a lot, they like me, I get gifts from the customers, boxes of bonbons... There are gloves, gloves for cleaning the bathroom, everything's just perfect..." (P4). "The place is fine; I really liked it there... I had my own room, I had a an identification badge and my name was on the door... they gave me a birthday party" (P2).

Initially satisfactory social environment: "You could even say the place was good, the coworkers that is, but later there was so much gossip... every job has gossip, right?" (P9). 
Ambiguous: "They had a van that would take us there and pick us up... the van would pick us up there at the department and take us to the lunchroom at lunchtime, around eleven, eleven thirty" (P7).

\section{The Family's Role in Inclusion}

With respect to the family's role in the job-market inclusion process, the statements of several participants revealed that their families supported and helped them $(n=6)$; nonetheless, one account indicated that the family abstained from participating in the process, and two participants made no comments. The statements are presented below:

Support/Help: “My parents think it's great I'm working over there... They support me, help me, and treat me well, you know..." (P2).

My mom helped me out, gave me full support, because there are moms that don't 'oh, the kid is a goof' - yet are fearful people will fool you, all of that ... And now that I'm working, they continue to support me in the same way. (P3)

Non-involvement: "Then, my mom tells me I have to get a job, so I say... 'so, get one for me' ... And my dad insists, too..." (P6).

\section{Occupational Achievements}

This category's questions were only posed to the employed participants. With respect to the achievements that employment offers, the employed participants mentioned social development $(n=2)$, personal maturation $(n=1)$ and social recognition $(n=1)$. Examples of their statements are presented below:

Social development: "Uh, I've gained a lot of things... I began to interact with everybody, getting to know people..." (P4).

Personal maturation: "I learned from my friends, I matured, I grew over there..." (P2).

Social recognition: "I began to get more respect from people, a lot more appreciation..." (P3).

With respect to the income they received, the participants indicated that they spent it on material possessions, as one observes in the following accounts:
"Buying clothes." (P1). "I bought myself a radio, during Carnaval... and that's how it's been, buying sneakers now and then, a piece of clothing; when I can't afford something, I don't buy it...” (P3). “. . . I buy clothes, sneakers; I've already bought two pairs of sneakers, one for work and one for going out..." (P4).

\section{Occupational Expectations and Motives for Resigning}

With respect to the participants' occupational expectations, a question that was posed to the unemployed participants alone, they mentioned financial gains $(n=3)$, recognition of abilities $(n=1)$ and personal satisfaction $(n=1)$. In addition to the preceding, another account provided vague, imprecise information. Examples of the statements are presented below:

Financial gains: "Once I start working, it'll improve my life, help my dad and mom..." (P9) "It can change my situation even more..." (P7).

Recognition of abilities: "To be a successful ballerina and be recognized abroad, so that everyone sees that I'm fully capable of doing it..." (P8).

Personal satisfaction: "Everything, you know... my self-esteem will rise again...” (P6).

In light of the fact that all the unemployed participants had already worked previously, they mentioned the following motives for having left their last job: compliance/noncompliance with employment rules $(n=3)$, task learning difficulties $(n=1)$ and incompatibility with the job $(n=1)$, as demonstrated by the statements below:

Compliance/noncompliance with employment rules: "The contract ended, but I didn't want it anyway, I really didn't want it." (P8). "But, they didn't want to pay... so... in order to avoid further problems, I left" (P5).

Task learning difficulties: "It was hard for me to understand things there... I had to cut and sort things there; I had to use a heavy glove on my left hand..." (P9).

Incompatibility with the job: "I had to stay until late at night... and the lady thought I was too slow" (P6). 


\section{Discussion}

Analyzing and studying individuals with intellectual disabilities is a challenge for researchers; nonetheless, the present study's results demonstrate the feasibility of collecting data from such individuals. We came across vague statements as well as difficulties to describe some of the proposed topics on the part of the participants, yet our objectives were satisfactorily attained. The interview script we employed proved to be a highly effective data collection instrument, principally because it enabled us to explore, via verbal accounts, the job inclusion phenomenon (Lobato, 2009). The interview script was written taking into account the intellectually disabled participants' comprehension level, thus giving them a "voice." In spite of the great care taken in the preparation of the interview script, it still contained a few questions that several participants were unable to answer, most likely because they did not comprehend them. It is thus important to stress the necessity for better adaptation of the data collection instruments to the personal traits of the individual. It is evident that such a procedure can be a challenge for researchers. Nevertheless, performing pilot studies could minimize such situations.

The present study's results largely corroborate the findings of the literature on the subject, which stress workplace inclusion's importance to intellectually disabled adults' development and indicate the need to improve this process (Akkerman et al., 2014; Araújo \& Schmidt, 2006; Holwerda et al., 2013; Lobato, 2009; Masson, 2009; Pereira-Silva \& Furtado, 2012; Santilli et al., 2014; Tanaka \& Manzini, 2005). The intellectually disabled participants in our study consider the job-market inclusion process satisfactory, yet also unsatisfactory, it being both a right and a means of training their skills. As stated by the participants, work offers them both financial and personal gains, such as social development, maturity, a sense of being productive and social recognition, which are gains that are consistent with those identified in other studies (Akkerman et al., 2014; Santilli et al., 2014).
The literature identifies education and vocational training as prerequisites that are essential to workplace inclusion (Lobato, 2009; Masson, 2009; Nord et al., 2013). Nonetheless, in the present study, five participants had no formal education, although they had taken part in career workshops at specialized care institutions, and three of the five were employed at the time of data collection. Such a finding appears to indicate that, by itself, lack of schooling was not an obstacle to job inclusion and was thus not the only criterion for hiring individuals with IDs. The literature stresses that companies' lack of social accessibility and intellectually disabled individuals' lack of career training are the two major obstacles to such individuals' workplace inclusion (Araújo \& Schmidt, 2006; Lobato, 2009; Masson, 2009; Neves-Silva, Prais, \& Silveira, 2015; Nord et al., 2013; Paiva et al., 2015; Pereira-Silva \& Furtado, 2012). It is noteworthy that the most highly educated participant (P2), having graduated from high school, was working as a typist/office assistant for a metal manufacturing company. She had also frequented workshops ever since childhood. This finding bolsters the importance of schooling and workshops in terms of better job-market inclusion, but there is also a necessity for career training and vocational preparation, for one unemployed participant had a high school diploma. It is worth highlighting that no one reported dissatisfaction with inclusion; nonetheless, there is still a great lack of opportunities, career training, job openings, and appreciation of intellectually disabled individuals, as was pointed out by Neves-Silva et al. (2015).

The participants' statements in relation to "what it means to be employed" reveal that they are clearly aware of what being employed offers them, especially in terms of autonomy, independence, personal satisfaction, productivity and responsibility, suggesting that the workplace environment can promote developmental advances, a notion that is in line with Bronfenbrenner's bioecological model (Bronfenbrenner \& Morris, 1998). With respect to personal development, a study by Akkerman et al. (2014) also identi- 
fied the importance attributed to work, whether in terms of developing social ties, abilities and skills, or autonomy.

It is worthwhile to stress the importance of companies in relation to creating an environment that promotes individual development and inclusive attitudes (Gomes-Machado \& Chiari, 2009; Nota et al., 2014), for the difficulty often lies not only in the intellectually disabled individual's workplace inclusion but also in his/her permanence (Cook, Foley, \& Semeah, 2016), principally due to companies' lack of social accessibility (Cook et al., 2016; Lobato, 2009; Masson, 2009). The present study did not yield many accounts of difficulties in relation to the participants' inclusion process, although several of the participants considered their inclusion unsatisfactory and their work environment slightly inadequate. Hence, as underscored by Nota et al. (2014), there is a need to conduct interventions in companies, seeking to eradicate employers' bias in relation to hiring individuals with disabilities, especially intellectual disabilities.

With respect to the family's role in the employment inclusion process, the majority of the participants referred to their families as being supportive, families that offered them emotional support, encouraged them and aided them during the entire course of the inclusion process. On the other hand, one participant mentioned noninvolvement in the inclusion process on the part of his family. Accordingly, one may conclude that the majority of the families exhibited some form of involvement in the inclusion of their intellectually disabled family member. There still is a lack of studies concerning the family's importance to adults with IDs and the family's impact on the inclusion process; nonetheless, the family can be considered essential to the successful inclusion of intellectually disabled individuals (Furtado \& Pereira-Silva, 2016; Pereira-Silva \& Furtado, 2012), as indicated by the present study's results. We recommend further research focusing on identifying potential correlations between inclusion effectiveness and family commitment, supporting interventions aimed at developing programs for families to promote workplace inclusion.

\section{Final Considerations}

It is of utmost importance for families, communities, specialized care institutions, schools and companies to establish support networks that are vital to the development of intellectually disabled individuals (Dallabrida, 2007; NevesSilva et al., 2015; Rosa \& Denari, 2013). Such diverse environments can be considered contexts of social development and inclusion. We thus underscore the importance of the role they play (especially the role of the family) as mediators of relationships between intellectually disabled individuals and other contexts, such as the workplace environment (Bronfenbrenner \& Morris, 1998). The employment context is capable of effectively promoting the development of persons with IDs (Akkerman et al., 2014; Santilli et al., 2014), a fact that is in line with the present study's results, especially when the participants' accounts of personal development and satisfaction are associated with the workplace inclusion process.

It is worth stressing that the present study's data is based on the statements of a small sample of intellectually disabled adults from a city in the interior of the state of Minas Gerais, Brazil, a fact that places several limitations on the considerations made here. We thus underscore the importance of conducting further studies, focusing on better understanding the inclusion process and improving its effectiveness. In order to do so, we recommend that future research be aimed at performing systemic analysis, collecting data from a wide diversity of participants, such as family members, employers, coworkers, and specialized care institution experts. Research focusing on a better understanding of the job-market inclusion process and its impact on intellectually disabled individuals' development is highly relevant to both the comprehension of human development and the planning and implementation of public policies on inclusion. 


\section{References}

Akkerman, A., Janssen, C. G. C., Kef, S., \& Meininger, H. P. (2014). Perspectives of employees with intellectual disabilities on themes relevant to their job satisfaction: An explorative study using photovoice. Journal of Applied Research in Intellectual Disabilities, 27, 542-554. doi: 10.1111/jar.12092

Almeida, L. A. D., Carvalho-Freitas, M. N., \& Marques, A. L. (2010). Inserção no mercado formal de trabalho: Satisfação e condições de trabalho sob o olhar das pessoas com deficiência. In M. N. Carvalho-Freitas \& A. L. Marques (Eds.), O trabalho e as pessoas com deficiência: Pesquisas, práticas e instrumentos de diagnóstico (pp. 89-105). Curitiba, PR: Juruá.

Aranha, M. S. F. (2001). Paradigmas da relação da sociedade com as pessoas com deficiência. Revista do Ministério Público do Trabalho, 21, 160-173. Retrieved from http://www.anpt.org. br/index2.jsp?tipo_noticia $=7 \&$ pagina_ $=3$

Araújo, E. A. C., Escobal, G., \& Ribeiro, D. M. (2006). Planejamento e organização de serviços para a formação de pessoas com deficiência mental para o trabalho. In C. Goyos \& E. Araújo (Eds.), Inclusão social: Formação do deficiente mental para o trabalho (pp. 143-166). São Carlos, SP: RiMa.

Araújo, J. P., \& Schmidt, A. (2006). A inclusão de pessoas com necessidades especiais no trabalho: A visão de empresas e de instituições educacionais especiais na cidade de Curitiba. Revista Brasileira de Educação Especial, 12, 241-254. doi: 10.1590/S1413-65382006000200007

Barbosa-Gomes, J. F., \& Carvalho, M. O. (2010). O profissional com deficiência e o mercado de trabalho: Parceria de sucesso. In M. N. Carvalho-Freitas \& A. L. Marques (Eds.), Trabalho e pessoas com deficiência: Pesquisa, práticas e instrumentos de diagnóstico (pp. 201-212). Curitiba, PR: Juruá.

Brazilian Constitution. (1988). Promulgada em 5 de outubro de 1988 e atualizada até a Emenda Constitucional $\mathrm{n}^{\mathrm{o}} 88$, de 15 de setembro de 2015. Retrieved from http://www.planalto.gov.br/ccivil_03/Constituicao/Constituicao.htm

Bronfenbrenner, U., \& Morris, P. A. (1998). The ecology of developmental processes. In W. Damon \& R. M. Lerner (Eds.), Handbook of child psychology: Theoretical models of human development (pp. 993-1028). New York: Wiley.

Cezar, K. R. (2010). As pessoas com deficiência intelectual e o direito à inclusão no trabalho: A efetividade da lei de cotas (Master thesis, Universidade de São Paulo, SP, Brazil).

Cook, L. H., Foley, J. T., \& Semeah, L. M. (2016). An exploratory study of inclusive worksite wellness: Considering employees with disabilities. Disability and Health Journal, 9, 100-107. doi: 10.1016/j.dhjo.2015.08.011

Dallabrida, A. M. (2007). As famílias e a classe especial em um colégio de elite. Revista Brasileira de Educação Especial, 13, 459-478. doi: 10.1590/S1413-65382007000300011

Dessen, M. A., \& Cerqueira-Silva, S. (2009). Desenvolvendo sistemas de categorias com dados de entrevistas. In L. Weber \& M. A. Dessen (Eds.), Pesquisando a família: Instrumentos para coleta e análise de dados (pp. 43-56). Curitiba, PR: Juruá.

Federal Law No. 8112. (1990). Dispõe sobre o regime jurídico dos servidores públicos civis da União, das autarquias e das fundações públicas federais. Retrieved from http://www.planalto. gov.br/ccivil_03/leis/L8112cons.htm

Federal Law No. 8213. (1991). Dispõe sobre os Planos de Benefícios da Previdência Social e dá outras providências. Diário Oficial da República Federativa do Brasil. Retrieved from http:// www.planalto.gov.br/ccivil_03/leis/18213cons. htm

Federal Law 13,146 of July 2015. (2015). Institui a Lei Brasileira de Inclusão da Pessoa com Deficiência (Estatuto da Pessoa com Deficiência). Retrieved from http://www.planalto.gov.br/ccivil_03/_ato2015-2018/2015/lei/113146.htm

Furtado, A. V., \& Pereira-Silva, N. L. P. (2014). Trabalho e pessoas com deficiência intelectual: Análise da produção científica. Revista Brasileira de Orientação Vocacional, 15(2), 213-223. doi: http://pepsic.bvsalud.org/scielo.php?script $=$ sci arttext\&pid $=$ S1679-33902014000200011

Furtado, A. V., \& Pereira-Silva, N. L. (2016). Deficiência intelectual e trabalho: A inclusão segundo os membros familiares. In N. L. Pereira-Silva, A. G. Barbosa, \& M. C. Rodrigues (Eds.), Pesquisas em desenvolvimento humano e educação (pp. 273-296). Curitiba, PR: CRV. 
Gold, P. B., Fabian, E. S., \& Luecking, R. G. (2013). Job acquisition by urban youth with disabilities transitioning from school to work. Reabilitation Cousenling Bulletin, 57(1), 31-45. doi: $10.1177 / 0034355213481248$

Gomes-Machado, M. L., \& Chiari, M. B. (2009). Estudo das habilidades adaptativas desenvolvidas por jovens com síndrome de Down incluídos e não incluídos no mercado de trabalho. Saúde $e$ Sociedade, 18, 652-661. doi: 10.1590/S010412902009000400009

Holwerda, A., van der Klink, J. J. L., de Boer, M. R., Groothoff, J. W., \& Brouwer, S. (2013). Predictors of work participation of young adults with mild intellectual disabilities. Research in Developmental Disabilities, 34, 1982-1990. doi: 10.1016/j.ridd.2013.03.018

Instituto Brasileiro de Geografia e Estatística. (2012). Censo Demográfico 2010: Características gerais da população, religião e pessoas com deficiência. Retrieved from http://www.ibge.gov.br/ home/estatistica/populacao/censo2010/caracteristicas_religiao_deficiencia/default_caracteristicas_religiao_deficiencia.shtm

Kirsh, B., Stergiou-Kitab, M., Gewurtz, R., Dawson, D., Krupa, T., Lysaght, R., \& Shaw, L. (2009). From margins to mainstream: What do we know about work-integration for persons with brain injury, mental illness and intellectual disability? Work, 32, 391-405. doi: 10.3233/WOR-20090851

Lobato, B. C. (2009). Pessoas com deficiência no mercado de trabalho: Implicações da lei de cotas (Unpublished master thesis, Centro de Educação e Ciências Humanas, Universidade Federal de São Carlos, SP, Brazil).

Lysaght, R., Cobigo, V., \& Hamilton, K. (2012). Inclusion as a focus of employment-related research in intelectual disabity from 2000 to 2010: A scoping review. Disability \& Rehabilitation, 34(16), 1339-1350. doi: 10.3109/09638288.2011.644023

Lysaght, R., Petner-Arrey, J., Cobigo, V., \& OulletteKuntz, H. (2014). Work preparation and participation in Ontario for persons with intellectual and development disabilities - A cross-region analysis. Journal on Developmental Disabilities, 20(2), 34-43. Retrieved from http://www. oadd.org/docs/41018_JoDD_20-2_v10f_34-43_ lysaght_et_al.pdf
Mantoan, M. T. E. (2015). Inclusão escolar: O que é? Por quê? Como fazer? São Paulo, SP: Summus.

Masson, M. J. B. (2009). Educação e trabalho: A constituição do trabalhador deficiente intelectual (Unpublished master thesis, Universidade Metodista de Piracicaba, Piracicaba, SP, Brazil).

Mendes, E. G. (2006). A radicalização do debate sobre inclusão escolar no Brasil. Revista Brasileira de Educação, 11(33), 387-405.

Morin, D., Rivard, M., Crocker, A. G., Boursier, C. P., \& Caron, J. (2013). Public attitudes towards intellectual disability: A multidimensional perspective. Journal of Intellectual Disability Research, 53(3), 279-292. doi: 10.1111/jir.12008

Neves-Silva, P., Prais, F. G., \& Silveira, A. M. (2015). Inclusão da pessoa com deficiência no mercado de trabalho em Belo Horizonte, Brasil: Cenário e perspectiva. Ciência \& Saúde Coletiva, 20(8), 2549-2558. doi: 0.1590/141381232015208.17802014

Nord, D., Luecking, R., Mank, D., Kiernan, W., \& Wray, C. (2013). The state of the science of employment and economic self-sufficiency for people with intellectual and developmental disabilities. Intellectual and Developmental Disabilities, 51(5), 376-384. doi: 10.1352/19349556-51.5.376

Nota, L., Santilli, S., Ginevra, M. C., \& Soresi, S. (2014). Employer attitudes towards the work inclusion of people with disability. Journal of Applied Research in Intellectual Disabilities, 27, 511-520. doi: 10.1111/jar.12081

Paiva, J. C. M., Bendassolli, P. F., \& Torres, C. C. (2015). Sentidos e significados do trabalho: Dos impedimentos às possibilidades do trabalho de pessoas com deficiências. Estudos e Pesquisas em Psicologia, 15(1), 218-239. Retrieved from http://www.e-publicacoes.uerj.br/index.php/revispsi/article/view/16071/12091

Pereira-Silva, N. L., \& Furtado, A. V. (2012). Inclusão no trabalho: A vivência de pessoas com deficiência intelectual. Interação em Psicologia, 16(1), 95-100. doi: http://dx.doi.org/10.5380/ psi.v16i1.23012

Rosa, F. D., \& Denari, F. E. (2013). Trabalho, educação e família: Perspectivas para a pessoa com deficiência intelectual. Revista Educação Especial, 26(45), 73-90. Retrieved from http://www. redalyc.org/articulo.oa? $\mathrm{id}=313128573006$ 
Santilli, S., Nota, L., Ginevra, M. C., \& Soresi, S. (2014). Career adaptability, hope and life satisfaction in workers with intellectual disability. Journal of Vocational Behavior, 84(1), 21-30. doi: 10.1016/j.jvb.2014.02.011

Sassaki, R. K. (1997). Inclusão. Construindo uma sociedade para todos $\left(3^{\text {rd }}\right.$ ed.). Rio de Janeiro, RJ: WVA.

Tanaka, E. D. O., \& Manzini, E. J. (2005). O que os empregadores pensam sobre o trabalho da pessoa com deficiência? Revista Brasileira de Educação Especial, 11, 273-294. doi: 10.1590/ S1413-65382005000200008

Vieira, C. M., \& Denari, F. E. (2008). Concepções infantis sobre a deficiência mental: Efeitos de um programa informativo. In M. A. Almeida, E. G. Mendes, \& M. C. P. I. Hayashi (Eds.), Temas em educação especial: Deficiências sensoriais e deficiência mental (pp. 289-297). Brasília, DF: PROESP.
Vornholt, K., Uitdewilligen, S., \& Nijhuis, F. J. N. (2013). Factors affecting the acceptance of people with disabilities at work: A literature review. Journal Occupational Reahabilitation, 23(4), 463-473. doi: 10.1007/s10926-013-9426-0

World Health Organization. (1948). Resolução 217, de 10 de dezembro de 1948. Declaração Universal dos Direitos Humanos. Retrieved from http:// www.dudh.org.br/wp-content/uploads/2014/12/ dudh.pdf
Recceived: 05/08/2016

$1^{a}$ revision: $30 / 06 / 2017$ Accepted: 16/07/2017 